\title{
Dawid Kopa
}

Uniwersytet Pedagogiczny im. Komisji Edukacji Narodowej w Krakowie e-mail: kdavid@o2.pl

\section{Ostatnia odsłona rzeczywistości Jana K.}

Słowa kluczowe: filozofia, estetyka, socjologia kultury, literaturoznawstwo, sztuka

Finis opus coronat. Ostania książka Jana Kurowickiego ${ }^{1}$ zatytułowana Estetyczne przysłony rzeczywistości ${ }^{2}$ stanowi rozwinięcie, doprecyzowanie i podsumowanie zagadnień z kręgu tematycznego, jaki przewija się w twórczości tego filozofa, eseisty, poety i dramaturga już od blisko 40 lat $^{3}$. Nowe spojrzenie na estetykę zaproponowane przez Kurowickiego uznaje za równouprawnione metody poszukiwań poznawczych czerpanych z dorobku filozofii, socjologii kultury, literaturoznawstwa i historii sztuki. Każda z tych dyscyplin stanowi źródło empirycznych egzemplifikacji dla przyjmowanych założeń teoretycznych.

Na początku autor przenosi nas w świat „zerowości estetycznej”. To ukute przez Kurowickiego pojęcie opisuje dominujący komponent form literatury i sztuki obecny

1 Jan Kurowicki nie żyje od 11 października 2017 r. Jego grób znajduje się w Jeleniej Górze, www.ezit.ue.wroc.pl (30.03.2018).

2 Wprawdzie na okładce książki znajdujemy tytuł Estetyczne przesłony rzeczywistości, jednak z tytułu zamieszonego na s. 1 oraz 3, a także z treści dzieła możemy wnioskować, że autor chciał książce nadać tytuł: Estetyczne przysłony rzeczywistości. J. Kurowicki, Estetyczne przystony rzeczywistości (Eseje z nowej estetyki spolecznej), Warszawa 2016, s. 1, 3.

3 J. Kurowicki, Miraże świadomości estetycznej. Miejsce kategorii estetycznych w materializmie historycznym, Warszawa 1982; idem, Piękno i poznanie. Studium kategorii estetyki jako filozofii historii kultury, Opole 1992; idem, Kultura jako źródło piękna, Warszawa 1997; idem, Fotografia jako zjawisko estetyczne, Toruń 1999; idem, Piękno jako wyraz dystansu: wykład estetyki z perspektywy filozofii kultury, Warszawa 2000; idem, Zerowość estetyczna, Warszawa 2008; idem, Estetyczność środowiska naturalnego, Warszawa 2010. 
W naszej codzienności. Przybliżenia definicji zerowości estetycznej autor dokonał w następujących słowach:

Dlatego powiada się, że w każdej praktyce artystycznej istnieje granica, której artyście przekraczać nie wolno. Powyżej niej znajdują się dzieła o jakościach estetycznie pozytywnych; poniżej - negatywnych. Ale czym jest sama ta granica? Bezwymiarową linią, oddzielającą jedne od drugich? Czy też przestrzenią dla dzieł ani pozytywnych jakościowo, ani negatywnych, tylko estetycznie żadnych, zerowych? ${ }^{4}$

Jak zauważa Kurowicki, od czasów przełomu poznawczego, który miał miejsce w nowożytności, rzeczy przestały mieć wymiar szczególnych widzialnych elementów zakorzenionych w świecie duchowym. Empiryczne spojrzenie na przyrodę postawiło je jako element porządku dnia codziennego, czyli niejako niezauważalne tło naszego życia. W obrazach Rembrandta dostrzegamy rzeczy, które chcą przekroczyć ten porządek zwykłości i codzienności.

Ale sprawa amor intellectualis ma głębsze podłoże. Co bowiem pozwalało wspomnianemu przezeń Rembrandtowi zwykłe rzeczy opromieniać aureolą, jak innym artystom tylko postacie świętych? Co w ogóle kryje się za działaniami nowożytnych i współczesnych artystów, którzy wydobywają rzeczy ze skorupy zwykłości, by mogła zaistnieć, choćby w przytłumionej postaci, owa doktryna miłości?

Sądzę, że kontemplacja o zmienionej po średniowieczu postaci.

Wtedy bowiem, kiedy średniowiecze kwitło, była ona poznawczym sposobem, aby w aktach skupienia się na rzeczach, zjawiskach i przedstawieniach wyobraźni dostąpić obecności sacrum. Nasączone nią przecież zdawały się najzwyklejsze nawet przedmioty i imaginacje. Nic bez niego czy obok nie mogło trwaćs.

W dalszej części książki Kurowicki zaprezentował nam przyczyny, dla których „ozdoba zdobi”. Prześledził dawne korzenie współczesnego wyglądu ozdób. Zaobserwował relacje między zdobiącym a zdobionym. Ukazał społeczną rolę prezentacji nadmiaru, jakim jest ozdoba. Dostrzegł zmianę, jaka zaszła w jej wyglądzie i funkcjach. Była ona wynikiem zastępowania ozdób roślinnych i zwierzęcych (jakie w przemijających obecnie kulturach towarzyszyły ceremoniom religijnym i innym rytom przejścia) przez przedmioty, których znaczenie odnosi się do ich związku z treściami sączonymi przez współczesną cywilizację kanałami kina, radia, telewizji, internetu itp. ${ }^{6}$

4 J. Kurowicki, Estetyczne przysłony..., s. 15.

5 Ibidem, s. 37-38.

6 Ibidem, s. 58-74. 
Do fikcji stanowiących jeden z elementów oliwiących mechanizm współczesnego społeczeństwa autor zalicza wyobrażenie ogrodu jako raju - emanacji dziewiczości natury. Kurowicki demaskuje współczesną naturę jako twór kulturowy ${ }^{7}$. Henryk Jurkowski, który nie traktuje ludzkiego obrazu natury wyłącznie jako tworu kulturowego, podziela jednak częściowo punkt widzenia Kurowickiego, co jest dowodem pewnej jego nieodpartości.

Treść ikonosfery, z przyczyn oczywistych, była determinowana przez naturalne otoczenie człowieka, ale działały tu również inne czynniki, które dokonywały jej transformacji zgodnie z istniejącą sytuacją religijną i polityczną, typową dla danej ludzkiej społeczności. Ikonosfera wytworzona przez człowieka miała ogromny wpływ na wyobraźnię i w szerszym sensie na kulturę każdego wstępującego pokolenia. Początkowo był to wpływ równie silny, co wpływ rzeczywistości percypowanej bezpośrednio, z czasem zaś, wraz z rosnącą rolą ludzkiej kultury, niepomiernie silniejszy, wręcz dominujący ${ }^{8}$.

Elementem kultury jest też każdy opis powstały w wyniku obserwacji natury. Stare relacje są źródłem przedzałożeń i toposów wykorzystywanych do tworzenia nowych. Z biegiem czasu wpływ bagażu kulturowego na kolejne powstające opisy jest stale rosnący. Zdaniem Kurowickiego obecnie nie istnieje już żadna relacja o naturze niewyrastająca $\mathrm{z}$ warstw kultury9 . Podobny sposób myślenia, lecz tylko jako jedną z dwóch prezentowanych koncepcji, przedstawiła Maria Gołaszewska. Otóż jej zdaniem człowiek sprowadza percypowane twory natury do tego, co jest mu już znane z życia codziennego lub sztuki. Najpierw odbierana przyroda ulega strukturyzacji w formy geometryczne i dopiero tak ukształtowany kulturowo obraz staje się źródłem przeżyć estetycznych ${ }^{10}$. Jej opinia na ten temat nie pojawiła się jednak od razu w gotowym kształcie. We wcześniejszym okresie prezentowała pogląd, że „można mniemać, że człowiek najpierw dostrzegał piękno w naturze, zanim je zaczął tworzyć w sztuce, choć doznania jego w tym zakresie były zapewne odmienne od tych, które występują dziś"

W swojej pracy Kurowicki śledzi rozwój społecznej roli ogrodu na przestrzeni wieków. Zaczyna od najwcześniejszych ogrodów stanowiących oazę natury uporządkowanej, będącej miejscem wypoczynku dla klas nieobarczonych obowiązkiem pracy fizycznej. Przechodzi do ogrodów będących materializacją romantycznego

\footnotetext{
7 Ibidem, s. 76-81.

8 H. Jurkowski, Przemiany ikonosfery. Wizualny kontekst sztuki teatru, Wrocław 2009, s. 10.

9 J. Kurowicki, Estetyczne przysłony..., s.76.

10 M. Gołaszewska, Estetyka pięciu zmystów, Warszawa 1997, s. 23.

11 M. Gołaszewska, Zarys estetyki. Problematyka, metody, teorie, Warszawa 1986, s. 86.
} 
marzenia o człowieku nieokiełznanym w swoich popędach, kontemplującym równie „nieokiełznaną” naturę ogrodu angielskiego. Dochodzi do współczesnych uporządkowanych przydomowych ogródków i miniaturowych ogródków działkowych, w których wszystko jest efektem pracy właściciela, a nie natury. Te współczesne miniogródki są wbrew świadomości ich użytkowników jedynie miejscem regeneracji sił służących wytwarzaniu towarów i usług ${ }^{12}$. Cały wywód autora stanowi żywe zaprzeczenie punktu widzenia Josepha Margolisa:

Powiedzieć, że dzieła sztuki są intencjonalne, to powiedzieć jedynie, w rozumieniu kantowskim, że wykazują wewnętrzną celowość; są utworzone z pociągnięć pędzla, kroków wyrażeń i tym podobnie. Nie znaczy to, że dzieła sztuki są o czymś w ogóle, chociaż powieści i wiersze są intencjonalne również i w tym znaczeniu. Lecz architektura, muzyka, wystrój ogrodów i dywany nie są zwykle o czymś, nie odnoszą się one do niczego ani niczego nie oznaczają ${ }^{13}$.

Przywołałem ten fragment, aby podkreślić wartość i świeżość wywodów $\mathrm{Ku}$ rowickiego. Zwrócić uwagę na fakt, iż bynajmniej nie cieszą się one powszechną akceptacją, nie tylko w odniesieniu do ogrodów. Dzieje się tak, ponieważ ekonomicznych przyczyn historycznego kształtowania się estetyki najwygodniej jest nie zauważać.

Piękno jest obecne w kulturze współczesnej, głównie jako punkt odniesienia dla szczególnie intensywnie eksploatowanej wartości estetycznej brzydoty. Nie jest dzisiaj w sztuce profesjonalnej dominujące to rozumienie piękna, którym posługiwali się starożytni Grecy. Władysław Tatarkiewicz starał się przybliżyć spojrzenie przeciętnego Greka na piękno w taki oto sposób:

Oznaczał bowiem wszystko to, co się podoba, pociąga, budzi uznanie. Zakres jego był więc szerszy. Oznaczał wprawdzie i to, co się podoba oczom i uszom, co się podoba ze względu na swój kształt czy budowę, ale oznaczał także wiele innych rzeczy, które podobają się na inny sposób i dla innych względów; obejmował widoki i dźwięki, ale także cechy charakteru, w których dzisiejszy człowiek widzi wartość innego rodzaju i jeśli je nazywa „pięknymi”, to ze świadomością, że wyrazu używa przenośnie. Świadectwem, jak Grecy pojmowali piękno, jest znane orzeczenie wyroczni delijskiej [sic!], że ,najpiękniejszym jest to, co najsprawiedliwsze". Z tego tak szerokiego i ogólnikowego pojęcia piękna, jakiego potocznie

12 J. Kurowicki, Estetyczne przystony..., s. 81-103.

13 J. Margolis, Dzieła sztuki jako byty ucieleśnione fizycznie $i$ wyłonione kulturowo, w: Estetyka w świecie. Wybór tekstów, t. II, red. M. Gołaszewska, tłum. W. Chojna, Kraków 1986, s. 210. 
używali Grecy, wytworzyło się, ale dopiero z czasem, powoli i z trudem, węższe, bardziej określone pojęcie piękna estetycznego ${ }^{14}$.

O ile jednak piękno istnieje współcześnie przede wszystkim jako konieczna antynomia brzydoty, o tyle wartość estetyczna brudu jest celowo pomijana. Lukę tę wypełnia Kurowicki, dostrzegając za przysłonami brzydoty i coraz rzadziej eksponowanego piękna ogromną rolę, jaką odgrywa brud jako element konieczny dla ustalonego przez cywilizacje ludzką kulturowego krajobrazu i kształtowanej przez działalność człowieka natury.

Samo środowisko naturalne traktuje się współcześnie bezwiednie... jako domenę czasu wolnego, przesyconą pozostałościami po sacrum. I takie właśnie jego wyobrażenie funkcjonuje w świadomości powszechnej. To, co je brudzi i zanieczyszcza, to nie rezultaty indywidualnego czy grupowego niechlujstwa. To - głównie obecność w nim pozostałości produkcyjnych i poprodukcyjnych lub „zakłócanie” środowiska przez urządzenia techniczne i technologiczne.

Chociaż - jak słusznie zauważa T. Adorno - przekonanie o estetycznym przeciwieństwie techniki i środowiska naturalnego jest błędne. Tam bowiem, gdzie pozostaje ono nie tknięte przez człowieka, może przypominać, jak powiada, nagromadzenie odpadów przemysłowych. Ma to, jego zdaniem, miejsce np. na alpejskich morenach, czy wśród zwałów skalnych. Technika - według autora „Teorii estetycznej” - raczej wspomaga przyrodę i pomaga jej, by mogła ona „stać się tym, czym by może chciała być".

Dodajmy jednak: gdyby mogła chcieć. Mogłaby wszak tylko wtedy, gdyby stanowiła podmiot, nie zaś coś, co przemawia do nas tylko naszym głosem, narzuconego jej przez określone stosunki społeczne i kulturę ${ }^{15}$.

Ten fragment pojawił się już książce Zerowość estetyczna ${ }^{16}$, lecz od tego czasu autor wprowadził zmiany do poprzedniej wersji tekstu. Po słowach „,traktuje się współcześnie” nie następowało: „bezwiednie - jak to pokazałem w poprzednim eseju -”. Zaś w swoich następnych myślach autor stwierdzał: ,jako domenę czasu wolnego, przesyconego pozostałościami po sacrum”, tymczasem w roku 2016 ten fragment ukazał się w brzmieniu: ,jako domenę czasu wolnego, przesyconą pozostałościami po sacrum". Zmianie uległa też treść ostatniego zdania w analizowanym fragmencie. Brzmiało ono: „Dodajmy: gdyby mogła chcieć. Mogłaby jednak tylko wtedy, gdyby

\footnotetext{
14 W. Tatarkiewicz, Historia Estetyki, t. I: Estetyka starożytna, Warszawa 1985, s. 37.

15 J. Kurowicki, Estetyczne przystony..., s. 110.

16 J. Kurowicki, Zerowość estetyczna, Warszawa 2008, s. 156.
} 
stanowiła podmiot, nie zaś coś, co przemawia do nas tylko naszym głosem, narzuconego jej przez określone stosunki społeczne i kulturę ładu" 17 .

Myślę, że wprowadzane przez Kurowickiego do tego fragmentu zmiany służyły przede wszystkim wzmocnieniu sugestywności przekazu. Niemniej trzeba zauważyć, że niekiedy odbyło się to z pewną szkodą dla jednoznaczności i klarowności wywodu. Są to jednak drobne potknięcia autora, który, co nie jest przecież obecnie regułą, nie miał żadnych problemów z przybliżaniem czytelnikowi skomplikowanych zagadnień teoretycznych. Zastępował często mętne metafory wymownymi przykładami.

Autor Estetycznych przyston rzeczywistości odsłania przed nami (w pewnym stopniu) sposób funkcjonowania oryginału w kulturze jako jakości estetycznej. Dostrzega historyczną zmienność, która doprowadziła do ukształtowania się tego pojęcia. Oryginalność odbioru wszelkich kulturowo ukształtowanych form determinują według Kurowickiego ich powidoki aksjologiczne, czyli nakładanie się na odbiór przedmiotów (w tym ludzi jako przedmiotów percepcji) ich znanych w kulturze korelatów. Oryginalność zaczęła stanowić o pozytywnym wartościowaniu kulturowo wytworzonych ,oryginałów” dopiero w nowożytności, albowiem:

W porządku sztuki natomiast oryginał staje się wartością dopiero wtedy, gdy jego obecność stanowi warunek akceptacji obiektu, jako przedmiotu estetycznej kontemplacji i handlowej manipulacji. Wtedy zaś liczy się autentyzm materiału, z jakiego został on wykonany, wierność reprezentowanemu stylowi i gwarancja, że jest dziełem konkretnego twórcy itp., itd.

Warunek ten jednak ma charakter historyczny, a nie uniwersalny. Mógł on zaistnieć wówczas, gdy - po pierwsze - tradycjonalne ars ulega po średniowieczu rozszczepieniu na sztuki piękne i rzemiosło. Kiedy więc w kształtowaniu form wizualnych przestały obowiązywać normy wytwarzania wedle wzorów i naśladowania, określonych przez tradycyjne zasady; artysta zaś - jak już powiedziano - zaczął stopniowo wyswobadzać się z bezpośredniej zależności od mecenasów i funkcjonować na rynku sztuki. Po drugie - co miało znaczenie podstawowe - kiedy rynkowa cena wytworów wziętych artystów czyniła ich kopiowanie działalnością intratną i coraz mniej skomplikowaną, dzięki rozwojowi technik reprodukcji. Ale też - po trzecie - gdy równolegle z tym wyodrębnia się i nabiera znaczenia ludzka indywidualność; konkretne, prywatne ja, które - jako twórca - oferuje odbiorcy obecność siebie w tworze artystycznym, przysłaniając jego rynkowy charakter ${ }^{18}$.

Zbliżonym zagadnieniom poświęcił fragment swojej Estetyki filozoficznej Mirosław Żelazny. Jego konkluzje jednak (jak sądzę nieprzypadkowo) nie dotykają istoty problemu, lecz jedynie omawiają jego przejawy. Fakt, że walor oryginalności nie ma charakteru ponadczasowego, umknął jego uwadze. To odbiór dzieła sztuki konsty-

\footnotetext{
17 Ibidem.

18 J. Kurowicki, Estetyczne przystony..., s. 137.
} 
tuuje jego wartość w świadomości odbiorcy. Dominującym elementem postrzegania dzieła sztuki jest jego funkcjonowanie w kulturze, a nie cechy przedmiotu same w sobie. Żelazny napisał:

Przykłady popierające tezę, że badanie materialnej substancji dzieła sztuki związane jest ze schodzeniem do coraz niższych rzędów wielkości jej istnienia, można oczywiście przytaczać w nieskończoność: rzeźby Michała Anioła to nie tylko wspaniałe bryły w trójwymiarowej przestrzeni, to również materia odpowiednio dobranego kamienia. Niezwykły efekt akustyczny uzyskiwany w Epidauros, gdzie dźwięk monety upuszczonej na scenie wyraźnie słyszy turysta znajdujący się w ostatnim rzędzie amfiteatru, również podobno jest efektem użycia odpowiednio dobranych rodzajów marmuru. Podobno, bo tajemnicy tej akustyki nikt właściwie do dziś nie rozwiązał. Dzieła sztuki pozostawione nam przez dawnych geniuszy za pięknym opakowaniem wartości estetycznych kryją jeszcze wiele tajemnic. Zbliżamy się do nich, tylko obcując z oryginałem. Tylko on może być strażnikiem prawdy, skumulowanej w jakiejś małej lub wielkiej historii ${ }^{19}$.

Kolejnym zagadnieniem ogniskującym uwagę Kurowickiego jest estetyczność pamiątki. Rzuca on snop światła na pamiątkę jako element kształtowania tożsamości własnego ja jednostki - pozostającego w kontrze do reszty społeczeństwa ${ }^{20}$. Nie pomija też w swoim zainteresowaniu pamiątki jako materialnego wyrazu pamięci zbiorowości ${ }^{21}$. Do jej konstytutywnych cech w obydwóch tych przypadkach zalicza fakt, że sama nie posiada znaczenia jako przedmiot (często będący przedmiotem masowego handlu i estetycznie mierny), lecz swoją wartość czerpie ze związanych z nią osobistych skojarzeń jednostki. Rzecz trwa jako pamiątka, dopóki istnieją te skojarzenia. Jest zatem kolejnym przedmiotem materialnym, który oddziałuje na pozostającego z nim w kontakcie człowieka za pomocą powidoku aksjologicznego.

Nie umknęła uwadze Jana Kurowickiego waga zabytku jako świeckiej świętości żywiącej się zyskami branży turystycznej i kulturalnej, żerującej na otaczającej go w świadomości społecznej aurze szlachetnej (tylko dlatego, że niedzisiejszej) niezwykłości:

W kulturze współczesnej, w której resztki żywej świętości religijnej coraz szybciej zamierają, obiekty postrzegane jako zabytki, a jednocześnie będące przedmiotami kultu religijnego, mają status dwuznaczny. Należą bowiem zarazem do sfery

19 M. Żelazny, Estetyka Filozoficzna, Toruń 2009, s. 299. Żelazny reprezentuje odmienne od Kurowickiego spojrzenie na poruszaną tematykę. Znalezienie w Estetyce filozoficznej myśli tego autora pozbawionej argumentów z arsenału teleologii witalistycznej nie było łatwe i zakończyło się porażką.

20 J. Kurowicki, Estetyczne przystony..., s. 138-142.

21 Ibidem, s. 142-146. 
religijnej i świętości świeckiej, wspólnotowej, co u wyznawców kultu wywołać może wewnętrzny dysonans. Chociaż przechodzi się najczęściej na tym do porządku: splata się nabożność zwiedzającego turysty z jego nabożnością religijną. Sprzeczność wtedy znika, a przeżycie estetyczne dopełnia religijne.

Jeżeli nie - to zdarzają się sytuacje, jak ta, którą opisała jedna z gazet codziennych: ponieważ w jednej z wsi zielonogórskich wnętrze zabytkowego kościoła, ozdobione freskami, wydawało się proboszczowi brudne - po prostu kazał je zamalować, bo brud to przecież „rzecz nie na miejscu”. Ostało się tedy „czyste” miejsce dla kultu. Świecka świętość przegrała. Oburzył się wprawdzie na to dziennikarz i konserwator zabytków, ale ksiądz postawił na swoim. Takie zdarzenia należą jednak do zanikających. Nie dlatego, że świecka świętość, czyli zabytek, zwycięża. Z tej przyczyny, że zabytki stwarzają liczne możliwości dobrych interesów ${ }^{22}$.

Ten sam fragment znalazł się już w książce Kultura jako źródło piękna. Wprowadzenie. Niemal dwie dekady, jakie dzielą powtórne ukazanie się tego tekstu, zaowocowały jednak drobnymi, choć charakterystycznymi zmianami świadczącymi o doskonaleniu przez autora z biegiem lat formy wypowiedzi i krystalizowaniu się jego obserwacji w coraz klarowniejszej postaci:

W kulturze współczesnej, w której resztki owej żywej świętości coraz szybciej obumierają, obiekty postrzegane jako zabytki, a jednocześnie będące przedmiotami kultu religijnego, mają status dwuznaczny. Należą bowiem zarazem do sfery sacrum i świętości świeckiej, co u wyznawców kultu wywołać może wewnętrzny dysonans. Chociaż najczęściej przechodzi się nad tym do porządku, splatając nabożność zwiedzającego turysty z jego nabożnością religijną. Sprzeczność wtedy znika, a przeżycie estetyczne dopełnia religijne. Oba zaś stanowią składniki przeżycia obrządku i przedmiotu zwiedzania. Jeżeli nie - to zdarzają się sytuacje także jak ta, którą opisała jedna z gazet codziennych: ponieważ ozdobione freskami wnętrze zabytkowego kościoła w jednej z wsi zielonogórskich wydawało się wiernym brudne - po prostu zamalowano ściany.

Brud - jak wcześniej pisałem - to rzecz nie na miejscu. Ostało się tedy „,czyste" miejsce dla kultu. Świecka świętość przegrała. Oburzył się wprawdzie na to dziennikarz i konserwator zabytków, ale proboszcz postawił na swoim. Takie zdarzenia należą jednak do zanikających. Nie dlatego, że świecka świętość, czyli zabytek, zwycięża, lecz z tej przyczyny, że zabytki stwarzają liczne możliwości dobrych interesów ${ }^{23}$.

Współcześnie zabytki są nowym rodzajem produktu, który choć nigdy sam się nie sprzedaje, to jednak jest motorem napędowym licznych usług towarzyszących

22 Ibidem, s. 167-168.

23 J. Kurowicki, Kultura jako źródto piękna. Wprowadzenie, Warszawa 1997, s. 125-126. 
zwiedzaniu. Turyście wydaje się, że jest mu dane przenieść się do lepszego dawnego świata (tylko dlatego lepszego, że dawnego), którego zabytek jest przeżytkiem. W istocie człowiek współczesny jest wystawiony na kontemplację produktu kulturowego przygotowanego przez specjalistów z różnych dziedzin. Zwiedzający bowiem może odbierać zabytek jedynie w perspektywie powidoku aksjologicznego.

Wśród przysłon rzeczywistości Kurowicki nie zapomina o fotografii, a w szczególności zjawisku dostrzegania fotogeniczności fotografowanych przedmiotów. Siła oddziaływania fotografii polega do pewnego stopnia na naszym złudnym przekonaniu o dokładnym odzwierciedleniu na zdjęciach obrazu rzeczywistości. Charakterystyczne jest jednak, że kiedy rzeczywistość przedstawiona na zdjęciu nie jest zgodna z naszymi kulturowo ukształtowanymi wyobrażeniami o niej, to przedstawiające ją zdjęcia uznajemy za niefotogeniczne. Z uwagi na fakt, że nawet najbardziej banalny obiekt może być na kolejnych zdjęciach odbierany przez widza w różny sposób, sztuka fotografii jest w niewielkim stopniu zagrożona zjawiskiem powszednienia i banalizacji wskutek powtarzania będących przedmiotem przedstawiania obiektów ${ }^{24}$. Widzimy, że fenomen nacechowanego afektem odbioru fotografii jest wciąż żywy. Zupełnie inaczej widział tę kwestię Jean Baudrillard:

Ten sam problem dotyczy fotografii, jeśli zamierzamy nadać jej postać multimedialną i wyposażyć we wszystkie możliwe środki służące do montażu, do komponowania kolaży, do obróbki cyfrowej i syntetycznej. To jej otwarcie w nieskończoność, owa deregulacja jest w gruncie rzeczy równoznaczna ze śmiercią fotografii, wyniesionej do poziomu performensu ${ }^{25}$.

Jednak to nie rzeczywista funkcja fotografii jest ważna, lecz jej społeczny odbiór. To społeczeństwo poprzez zachodzące w nim procesy jest ostatecznym podmiotem kształtującym postrzeganie sztuki, a przez nie i samą sztukę. W tym konkretnym wypadku fotografię.

Kurowicki oświetla także funkcjonowanie piękna związanego. Jest to ten rodzaj piękna, który zdarza się niejako przy okazji. Cechuje on często wyroby użytkowe, którym nie przypisujemy statusu dzieł sztuki. Interesujące jest dostrzeżenie piękna związanego w formach kampanii reklamowych wykorzystujących fotografię.

Jeszcze inaczej realizuje piękno związane fotografia reklamowa. Przyjrzyjmy się tedy różnym jej postaciom, czyniąc punktem wyjścia teorię i praktykę Oliviero Toscaniego, bo są one reprezentatywny [sic!] dla tematu.

Oto pokazuje w swej książce - „Reklama - uśmiechnięte ścierwo”, że gdy fotografie występują w obrębie reklamy - mają jedną cechę wspólną: są towarami, bo

24 J. Kurowicki, Estetyczne przysłony..., s. 172-183.

25 J. Baudrillard, Pakt jasności. O inteligencji zła, Warszawa 2005, s. 92. 
stoją za nimi określone formy przemysłu kulturowego, zajmujące się ich produkcją i reprodukcją. Zarazem - są twarzami czy opakowaniami wartości użytkowych rzeczy, obecnych w formie towarowej na rynku. Sprzedaje się więc je, aby coś innego mogło być sprzedawane. Jeżeli tak, to - od strony estetycznej - winny być rozpatrywane właśnie jako przejawy piękna związanego. Wyraża się ono w tym przypadku - w napięciu, jakie w odniesieniach międzyludzkich stwarza praktyka ekonomiczna. Praktyka ta, mówiąc w uproszczeniu, sytuuje między konsumentem a wytwórcą określone przedmioty (w tym przypadku - fotografie), które ich łączą ze sobą i zarazem oddzielają, jak robak na haczyku łączy i oddziela wędkarza od łowionej ryby ${ }^{26}$.

Maria Gołaszewska wspomina, że odbiorca sztuki rzadko ma świadomość jej zależności od kontekstu społeczno-ekonomicznego jej powstawania i to powiązanie nie wywiera wpływu na jej odbiór ${ }^{27}$. Trzeba tu powiedzieć, iż nawet jeżeli taka sytuacja w określonej, a nawet znacznej liczbie przypadków jest możliwa, to jednak nie można jej uznać za regułę powszechnie obowiązującą.

Jak zauważa Kurowicki, pewnym zaskoczeniem może być fakt, że do korzystających bez ograniczeń z możliwości tworzenia piękna wolnego należą grafomani oraz fotografowie amatorzy. Tworzą dla poklasku, którego najczęściej nigdy nie uzyskają, oraz będąc nieświadomi, iż współczesna praktyka artystyczna skazuje ich dokonania na usytuowanie w obrębie kiczu. Pozostają oni na ogół jednak twórcami szczęśliwymi. W samym akcie twórczym rozgrywa się u nich swoiste wywyższenie ego we własnych oczach. Strzepują z siebie kurz codzienności, zyskując status „,artysty”, nie wiedząc lub woląc nie wiedzieć, że na ogół kopiują jedynie stare maski z rupieciarni kultury, nawet jeżeli czasem powstają z tego interesujące kolarze ${ }^{28}$.

Kurowicki dokonuje przed czytelnikiem demistyfikacji samodzielnej roli sztuki w życiu społecznym. Wykorzystuje do tego celu zagadnienie funkcjonowania reprodukcji jej dzieł oraz albumów i opracowań. Zwraca uwagę na zjawisko zależności cen uznanych dzieł sztuki od stopnia rozpowszechnienia ich reprodukcji w kulturze popularnej. Nie umyka jego zainteresowaniu także rola sztuki jako nośnika promocji środków masowego przekazu. Odgrywa ona rolę nobilitującą dane medium w świadomości odbiorcy. Źródłem tej nobilitacji nie jest jednak wartość sztuki samej w sobie, lecz zbiór dotyczących jej, a obecnych w powszechnej świadomości stereotypów na temat poszczególnych zjawisk artystycznych. Lakonicznie konkretna wypowiedź autora ujmuje dosadnie relacje na linii sztuka-ekonomia:

26 J. Kurowicki, Estetyczne przystony..., s. 196.

27 M. Gołaszewska, Świadomość piękna. Problematyka genezy, funkcji, struktury i wartości w estetyce, Warszawa 1970, s. 176-177.

28 J. Kurowicki, Estetyczne przystony..., s. 201-207. 
Parafrazując Simmla z jego „Filozofii pieniądza”, można rzec, że w obszarze interesów pieniężnych, w których znajduje się dzisiaj sztuka, wszystkie jej wytwory są równowarte. Nie dlatego, że - jak mówił ten ekonomista i filozof - każdy z nich ma tę samą cenę, lecz że nic jej nie ma. Coś wart jest tylko pieniądz.

Takie jednak czysto racjonalno-ekonomiczne podejście do tematu „ekonomia i sztuka" zawiera w sobie coś niewątpliwie okrutnego. Choć sadystyczna rozkosz, płynąca z drastycznego i bezceremonialnego odnoszenia się do humanistycznej głębi sztuki, nie była bynajmniej motywem przedstawionego tu eseju. Ta bowiem drastyczność i sadyzm zjawiają się niejako samopas ${ }^{29}$.

Ta sama myśl została już wcześniej wyrażona przez Kurowickiego z mniejszą precyzją. Odzwierciedla to ewolucję stylu autora dokonującą się w czasie trwania jego długiego życia.

Po czwarte wreszcie - ceną tą jest podporządkowanie się sztuki tym kryteriom kultury wysokiej, które ustanawia (i - odpowiednio do swych potrzeb - zmienia) przemysł kulturowy. Powoduje to, iż granice między sztuką i nie sztuką stają się płynne. Parafrazując więc Simmla z jego Filozofii pieniądza, można rzec, że w obszarze interesów pieniężnych, wszystkie wytwory artystyczne są równowarte. Nie dlatego, że - jak mówił ten ekonomista i filozof - każdy z nich ma tę samą cenę, lecz że nic jej nie ma. Coś wart jest tylko pieniądz.

Takie jednak czysto racjonalne podejście do tematu „ekonomia i sztuka” zawiera w sobie coś niewątpliwie okrutnego. Ale sadystyczna rozkosz, płynąca z drastycznego i bezceremonialnego odnoszenia się do humanistycznej głębi sztuki, nie była bynajmniej motywem przedstawionego tu eseju! Chciałem ukazać tylko obraz stosunków i zależności między nią a praktyką produkcyjną i rynkiem, zgodnie z jego logiką, niezależnie od jakichkolwiek względów, nastrojów i subtelności ${ }^{30}$.

Kurowicki dostrzega, że tworzenie dzieł sztuki przez artystów amatorów oparte jest na imitacji. Sięgają oni do tych prądów w kulturze, które nie tętnią już żywym nurtem w otaczającej nas współczesności. Właśnie dzięki temu, że zastygły w swoim ostatecznym kształcie, stanowią atrakcyjną pożywkę dla tych twórców, którzy podchodzą bez koniecznego dla artystów profesjonalnych dystansu do materii twórczej i bez świadomości tkwiących w niej sprzeczności ${ }^{31}$.

Autor krytycznie odnosi się do możliwości swobodnego realizowania wolności twórczej w obecnej rzeczywistości społeczno-politycznej. Wraz ze zmianą ustroju nastąpiła też zmiana rodzaju barier stojących na drodze do swobodnej ekspresji artystycznej. Jak wspomina w ostatnim słowie - odnosząc się do sytuacji w Polsce:

\footnotetext{
29 Ibidem, s. 224-225.

30 J. Kurowicki, Zerowość estetyczna, Warszawa 2008, s. 99.

31 J. Kurowicki, Estetyczne przystony..., s. 226, 235.
} 
Powinno więc być to idealne miejsce dla artystycznych geniuszy w rozumieniu „Krytyki władzy sądzenie [sic!]”, czyli dla artystów, którzy tworzą bez żadnych ograniczeń i reguł, lecz analiza ich dzieł ukazuje jednak określone reguły: ich własne. Tymczasem łatwiej napotkać owe pomniki, przedrzeźniające się wzajem swą miernością, niż choć jednego takiego geniusza. A jeśli ten czy ów twórca próbuje nim być, uchodzi za dziwadło lub kończy jako skandalista. Tak lub inaczej spada na margines oficjalnego życia kulturalnego. Bez prestiżu i możliwości zarobku.

Coś więc z tą wolnością jest nie tak. Mimo bowiem braku cenzury praktyki artystyczne tkwią w swoistych zaciśniętych wędzidłach. Ta ziemia wszakże łatwo to znosi, jakby była stworzona do ich wytwarzania. Papież zaś z pomników wciąż jej błogosławi. I być może będzie tak, aż do dnia Sądu Ostatecznego. Boć łatwiej u nas wolność głosić, niż stworzyć dla niej rzeczywiste warunki obecności ${ }^{32}$.

Pochylając się nad ostatnim dziełem Kurowickiego, podsumowującym znaczną część jego dorobku twórczego, nie możemy powstrzymać się, aby z żalem nie zauważyć, że nie będziemy już mieć przyjemności płynącej z lektury nowych tekstów. Ożywcza myśl, jaką zrodziło jego doświadczenie, nie będzie już przeganiać z naszych głów mgły oczywistości. Dum vivit littera vivit et actio comissa litterae głosiły arengi niektórych średniowiecznych dokumentów. Niechaj ta nasza podróż przez ostatnią książkę Kurowickiego będzie żywym przedłużeniem oddziaływania zawartych w niej idei i zachętą do ich twórczego rozwinięcia przez kolejne pokolenia badaczy.

\section{THE LATEST REVELATION OF JAN K.'S REALITY}

Keywords: philosophy, esthetic, sociology of culture, literary studies, art

\section{Summary}

The article attempts to critically analyse the recent book by Jan Kurowicki Estetyczne przystony rzeczywistości (Eseje z nowej estetyki społecznej) [Aesthetic Apertures of Reality (Essays on the New Social Aesthetics)]. The author researches our everyday reality, seeking what is aesthetically marked. The author unveils the form and reception of aesthetic values which are socially determined. His book is a particularly important contribution to the ongoing discussion on the role of culture in the contemporary society.

32 Ibidem, s. 247. 